\title{
Physico-chemical Properties and Fish Composition of Ihawan Spring Community Watershed, Tandag, Surigao del Sur, Philippines
}

\author{
Melche D. Ojao ${ }^{1}$, Ecclesiastes E. Manatad ${ }^{1}$, Pepito A. Logronioํㅜㄹ Julianne T. Raz ${ }^{1}$, Maricris G. \\ Cudal $^{2 *}$, Arturo G. Gracia, Jr. ${ }^{1}$ \\ ${ }^{1}$ Surigao del Sur State University, Tandag City, Surigao del Sur, Philippines \\ ${ }^{2}$ Pagadian City International College, Zamboanga del Sur, Philippines
}

\section{Article history:}

Submission December 2020

Revised January 2021

Accepted April 2021

*Corresponding author:

E-mail: mcrisGcudal@gmail.com

\begin{abstract}
The first assessment study in aquatic ecosystem of Ihawan Spring Community Watershed revealed 23 species of fish belonging to 21 families from 22 genera. Species diversity is high, with values 1.88 and 0.42 , respectively for Shannon-Weiner Diversity Index ('H) and Simpsons Dominance (D). Out of the 21 families, Butidae and Eleotridae had the highest species composition (8.70\%). Interestingly, the fish composition of Ihawan Spring Community Watershed primarily composed of native (19 spp.), one (1 spp.) endemic, with two (2 spp.) recorded introduced species and one (1 spp.) Invasive Alien Species. The presence of dominant species of native species indicates the healthy state of the freshwater ecosystem of Ihawan Spring Community Watershed. However, the recently classified Invasive Alien Species of Oreochromis niloticus or Nile tilapia may attribute a negative impact in the river ecosystem that may result in the possible decline of native and endemic fish species present in the area. Whereas, the in- situ reading of some physico-chemical parameters like temperature, dissolved oxygen (DO) and $\mathrm{pH}$ of the Ihawan Spring Community Watershed river ecosystem revealed that all parameter tested have passed the standards set by the Philippine Water Quality Standards for Class AA (potable water) intended primarily for waters having watersheds which are inhabited and otherwise protected. From the findings, additional study especially on the abundance of recorded introduced and Invasive Alien Species is highly recommended to monitor the population abundance between the introduced, Invasive Alien Species, native and endemic species and to establish a real profile of the aquatic ecosystem of Ihawan Spring Community Watershed.
\end{abstract}

Keywords: Aquatic, Diversity, Invasive Alien Species, Freshwater fish, Native

\section{Introduction}

Freshwater ecosystem to-date face challenges worldwide and there has been no comprehensive global analysis of freshwater biodiversity available compare to those recently completed for terrestrial ecosystems [1]. Over the past 30 years, freshwater biodiversity has declined more quickly than the terrestrial and marine biodiversity [2]. Henceforth, paying little mind to its threats, the conservation endeavors keep on lingering a longways behind that of terrestrial and marine biodiversity [3]. To protect freshwater biodiversity, re- search studies on fish diversity, abundance, and distribution are crucial to developing management and conservation programs $[4,5]$. The ASEAN freshwater ecosystem is a home of 2,946 native, endemic, and introduced freshwater fish, of which 2, 875 are endemic and native species and 71 introduced species. The Philippines, which belongs to the ASEAN countries has a total of 3,010 ichthyofauna species of which 343 are freshwater dwellers [6]. Fish population have induced a wide cluster of ecological benefits among human. In

\section{How to cite:}

Ojao MD, Manatad EE, Logronio PA et al. (2021) Physico-chemical Properties and Fish Composition of Ihawan Spring Community Watershed, Tandag, Surigao del Sur, Philippines. Journal of Tropical Life Science 11 (3): 367 - 374. doi: 10.11594/jtls.11.03.13. 
terms of biodiversity, freshwater ecosystems are one of the richness [7].

Currently, the Philippine watershed areas face threats and are already in critical condition. One of the major identified contributing factors are deforestation and clear almost 2.6 million hectares of identified critical watershed areas of the country. Other anthropogenic activities that alter the land cover and land use of the watershed are forest fires, and agriculture-induced soil erosion that affects the watershed's quality. Land use alters the texture and composition of the land surface and therefore influences water quality. The water quality of the watershed is, therefore, influence by soil type, geology, vegetation, precipitation, land cover, and land use [8, 9]. Hence, the water quality of a river and other aquatic ecosystems in the watershed is characterized by high level of changes in time and space due to cover-land characterization [10].

Ihawan Spring Community Watershed (ISCW) is strategically located in Tandag City, in the province of Surigao del Sur of Southern Mindanao, Philippines. The watershed supplies drinking water to about $70 \%$ of the entire area of Tandag City and about 41,573 calculated households have benefited and provides water for agriculture, aquaculture, and domestic uses. Aside from its watershed importance, it is also the habitat of various flora and fauna. However, no scientific and up-to-date studies have been published nor extensively conducted in the area. Hence, the Local Government Unit of Tandag City stressed out that the consumption of resources from the watershed through various types of identified anthropogenic activities is one major source of ecological stressors, hence, the need to conduct assessment and monitoring studies in their watershed is very crucial. Thus, the focus of this study is to assess some physico-chemical properties and provide a checklist of the fish composition and abundance of the Ihawan Spring Community Watershed, Tandag, Surigao del Sur.

\section{Material and Methods \\ Study area and sampling sites}

A survey was done last August 2018 in Ihawan Spring Community Watershed freshwater ecosystem last August 2018. The Ihawan Spring Community Watershed with covering area of 784 ha of forest land is strategically located at Awasian ( $9^{\circ}$ $07^{\prime} 0^{\prime \prime} \mathrm{N}, 126^{\circ} 15^{\prime} 0^{\prime \prime} \mathrm{E}$ ), of Tandag City, province of Surigao del Sur. The area is covered by $50 \%$ natural and secondary growth forest, with at least $45 \%$ is utilized as agroforestry for crop productions like coconut, banana, falcata, and other fruitbearing trees. A total of 3 sampling stations per were established along with the river gradient stations, namely: upstream, midstream, and downstream (Figure 1). Survey was carried-out during

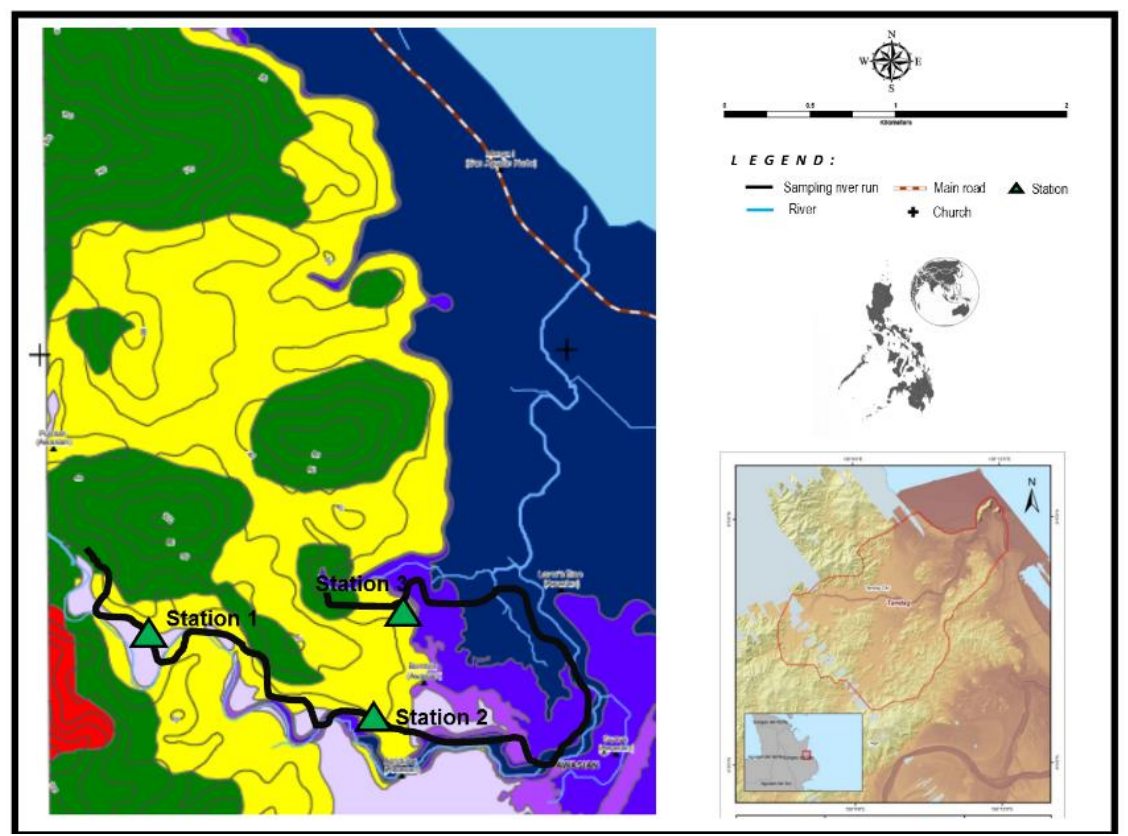

Figure 1. Modified map showing the sampling stations in Ihawan Spring Community Watershed, Awasian, Tandag City, Surigao del Sur, Philippines (CPhil-LIDAR) 
Table 1. Physicochemical parameters of Ihawan Spring Community Watershed, Tandag, Surigao del Sur, Phil-

\begin{tabular}{lllllll}
\multicolumn{1}{c}{ ippines } & & \multicolumn{1}{c}{} \\
\hline Parameters & Unit & Station 1 & Station 2 & Station 3 & Standards & Remarks \\
\hline Temperature & ${ }^{\circ} \mathrm{C}$ & 28.09 & 29.05 & 29.48 & $26-30$ & Within standards \\
$\mathrm{pH}$ & & 7.8 & 7.5 & 6.80 & $6.5-8.5$ & Above standards \\
Dissolved oxygen & $\mathrm{mg} / \mathrm{L}$ & 12.0 & 10.0 & 8 & $5(\mathrm{~min})$ & Within standards \\
\hline
\end{tabular}

Source: Department of Environment and Natural Resources (2016). DENR Administrative Order (DAO) No.

2016-08. Water Quality Guidelines and General Effluent Standards of 2016.

daytime in a 1-km sampling run that lasted for about 1.5 hour at each sampling stations. A total of seven-days of sampling was done in the month of August 2018.

The three sampling stations of Ihawan Spring Community Watershed (ISCW) was characterized by different vegetation cover and existing anthropogenic activities. The upstream are $\left(9^{\circ} 07^{\prime} 0306^{\prime \prime}\right.$ $\mathrm{N}, 126^{\circ} 14^{\prime} 0289^{\prime \prime} \mathrm{E}$ ) are characterized by high riparian vegetation, steep slope banks and rocky beds. The midstream $\left(9^{\circ} 07^{\prime} 0241^{\prime \prime} \mathrm{N}, 126^{\circ} 14^{\prime}\right.$ $0165^{\prime \prime} \mathrm{E}$ ) is characterized by semi-high vegetation cover and the substrate is rocky to sandy. Whereas, the downstream area $\left(9^{\circ} 07^{\prime} 0176^{\prime \prime} \mathrm{N}\right.$, $126^{\circ} 14^{\prime} 097^{\prime \prime} \mathrm{E}$ ) is characterized by low riparian vegetation, open canopy with exposure to direct sunlight. The station is surrounded by residential area, road construction, and use for domestic purposes such as bathing and washing clothes. Presence of carabao in the stream was also observed during the sampling.

\section{Physico-chemical parameters}

In-situ sampling was done to determine physico-chemical parameters of rivers and streams like water temperature, $\mathrm{pH}$, dissolved oxygen (DO), and carbon dioxide (CO2) using a handheld multiparameter AP-700 set device. Anthropogenic activities were also noted that may alter the results of the water quality during each fieldwork.

\section{Collection and identification of freshwater fish}

Fish samples were collected by employing a seine net and use of a hand net. Field guides, other scholarly published articles of freshwater fish in the Philippines, FishBase site [11] and verified to ichthyofauna experts were done for the identification of collected fish species. Morphometric and physical data of the collected species such as standard length, weight, color, number of fins, and other features were recorded in the site station. On-site photo documentation per species was done quickly to document the natural color of the fish that are useful in the species identification. Collected species that are rare and endangered were returned in the wild once identified, photo-documented, and measured.

\section{Data analysis}

Shannon-Weiner Diversity Index and Simpson's Dominance Index was used to analyze the quantitative composition and species dominance of the fish fauna collected in Ihawan Spring Community Watershed, Tandag, Surigao del Sur using Jasp version 0.9.2. Whereas, the species richness data was determined by counting the total number of fish species present in the sampling sites.

\section{Results and Discussions}

In this study, high $\mathrm{pH}$ value was recorded downstream (7.9) which could be attributed to its proximity to the community. This corroborates with the findings of $[12,13]$ where the frequent incidence of bathing and laundry was observed. Whereas, low $\mathrm{pH}$ value was recorded upstream (6.8) and is slightly acidic. The dissolved oxygen value pass the minimum standard set by Department of Environment and Natural Resources Administrative Order No. 2016-08 for Water Quality Guidelines and General Effluent Standards [14]. Among sampling stations, the downstream has the lowest reading of dissolved oxygen $(8 \mathrm{mg} / \mathrm{L})$ which could be attributed to its characteristic with shallow and is relatively flat and slow water movement. As presented in Table 1, the tested physicochemical parameters of this study passed some of the parameters set by the Philippine Water Quality Standards for Class AA or the Public Water Supply Class 1, intended primarily for waters having watersheds which are uninhabited and otherwise protected and which require only approved disinfection to meet the National Standards for Drinking Water (NSDW) of the Philippines.

Fluctuations of dissolved oxygen were record- 
Table 2. Checklist of collected fish species with percentage relative abundance per station and overall relative abundance per station in Ihawan Spring Community Watershed, Awasian, Tandag, Surigao del Sur (August 2018).

\begin{tabular}{|c|c|c|c|c|c|c|}
\hline Family/Species & $\begin{array}{l}\text { Common } \\
\text { Name }\end{array}$ & $\begin{array}{l}\text { IUCN } \\
\text { Status }\end{array}$ & Feeding Habit & Station 1 & Station 2 & Station \\
\hline \multicolumn{7}{|l|}{ Ambassidae } \\
\hline $\begin{array}{l}\text { Ambassis interrupta (Bleeker, } \\
\text { 1853) }\end{array}$ & $\begin{array}{l}\text { Long-spined } \\
\text { glass perchlet }\end{array}$ & $\mathrm{LC}$ & $\begin{array}{l}\text { Omnivorous, detritus and } \\
\text { plankton }\end{array}$ & & & 0.57 \\
\hline \multicolumn{7}{|l|}{ Anabantidae } \\
\hline $\begin{array}{l}\text { Anabas testudineus (Bloch, } \\
\text { 1792) }\end{array}$ & $\begin{array}{l}\text { Climbing } \\
\text { perch }\end{array}$ & $\mathrm{LC}$ & Algae, other invertebrates & - & 0.52 & 0.85 \\
\hline \multicolumn{7}{|l|}{ Anguillidae } \\
\hline $\begin{array}{l}\text { Anguilla marmorata (Quoy \& } \\
\text { Gaimard, 1825) }\end{array}$ & $\begin{array}{l}\text { Giant mottled } \\
\text { eel }\end{array}$ & $\mathrm{LC}$ & $\begin{array}{l}\text { Carnivorous, shrimps, small } \\
\text { frogs }\end{array}$ & 13.77 & 6.22 & 3.12 \\
\hline \multicolumn{7}{|l|}{ Apogonidae } \\
\hline $\begin{array}{l}\text { Archamia bleekeri (Günther, } \\
\text { 1859) }\end{array}$ & $\begin{array}{l}\text { Gon's cardi- } \\
\text { nal fish }\end{array}$ & NE & $\begin{array}{l}\text { Carnivorous, other inverte- } \\
\text { brates, plankton }\end{array}$ & - & - & 0.57 \\
\hline \multicolumn{7}{|l|}{ Butidae } \\
\hline Butis butis (Hamilton, 1822) & $\begin{array}{l}\text { Duckbill } \\
\text { sleeper }\end{array}$ & $\mathrm{LC}$ & $\begin{array}{l}\text { Carnivorous, shrimps and } \\
\text { prawns, small fish }\end{array}$ & - & - & 0.28 \\
\hline $\begin{array}{l}\text { Butis amboinensis (Valenci- } \\
\text { ennes, 1837) }\end{array}$ & $\begin{array}{l}\text { Olive flat- } \\
\text { head-gudgeon }\end{array}$ & $\mathrm{LC}$ & $\begin{array}{l}\text { Carnivorous, small fish, } \\
\text { worms, crustaceans }\end{array}$ & - & - & 0.28 \\
\hline \multicolumn{7}{|l|}{ Channidae } \\
\hline Channa striata (Bloch, 1793) & $\begin{array}{l}\text { Striped snake- } \\
\text { head }\end{array}$ & $\mathrm{LC}$ & $\begin{array}{l}\text { Carnivorous, insect, worms, } \\
\text { small fish }\end{array}$ & - & 0.52 & 0.57 \\
\hline \multicolumn{7}{|l|}{ Cichlidae } \\
\hline $\begin{array}{l}\text { Oreochromis niloticus (Lin- } \\
\text { naeus, 1758) }\end{array}$ & Nile tilapia & $\mathrm{LC}$ & $\begin{array}{l}\text { Native freshwater fish egg, } \\
\text { aquatic insects, algae, } \\
\text { plankton, shrimps }\end{array}$ & - & 2.07 & 3.68 \\
\hline \multicolumn{7}{|l|}{ Cyprinidae } \\
\hline $\begin{array}{l}\text { Puntius binotatus (Valenci- } \\
\text { ennes, 1842) }\end{array}$ & Spotted barb & $\mathrm{LC}$ & $\begin{array}{l}\text { Worms, insects, crusta- } \\
\text { ceans, organic debris, other } \\
\text { plant material, plankton }\end{array}$ & 61.54 & 58.03 & 60.62 \\
\hline \multicolumn{7}{|l|}{ Diodontidae } \\
\hline $\begin{array}{l}\text { Diodon holocanthus (Lin- } \\
\text { naeus, 1758) }\end{array}$ & $\begin{array}{l}\text { Longspinned } \\
\text { porcupinefish }\end{array}$ & $\mathrm{LC}$ & Crabs, snails & - & - & 0.28 \\
\hline \multicolumn{7}{|l|}{ Eleotridae } \\
\hline $\begin{array}{l}\text { Bostrychus expatria (Herre, } \\
\text { 1927) }\end{array}$ & & Vul & $\begin{array}{l}\text { Carnivorous, small crusta- } \\
\text { ceans }\end{array}$ & - & - & 0.28 \\
\hline $\begin{array}{l}\text { Giuris margaritacea (Valen- } \\
\text { ciennes, 1837) }\end{array}$ & $\begin{array}{l}\text { Snakehead } \\
\text { gudgeon }\end{array}$ & $\mathrm{LC}$ & $\begin{array}{l}\text { Omnivorous, other algae } \\
\text { and small fish }\end{array}$ & - & 1.55 & 1.42 \\
\hline \multicolumn{7}{|l|}{ Gobiidae } \\
\hline $\begin{array}{l}\text { Sicyopterus lagocephalus } \\
\text { (Pallas, 1770) }\end{array}$ & $\begin{array}{l}\text { Red-tailed } \\
\text { goby }\end{array}$ & $\mathrm{LC}$ & Micro algae & 24.70 & 17.62 & 7.93 \\
\hline \multicolumn{7}{|l|}{ Kuhliidae } \\
\hline $\begin{array}{l}\text { Kuhlia rupestris (Lacepède, } \\
\text { 1802) }\end{array}$ & Rock flagtail & $\mathrm{LC}$ & $\begin{array}{l}\text { Small fish, insects, crusta- } \\
\text { ceans, fruits that drop into } \\
\text { water }\end{array}$ & - & - & 0.28 \\
\hline \multicolumn{7}{|l|}{ Labridae } \\
\hline $\begin{array}{l}\text { Suezichthys gracilis } \\
\text { (Steindachner \& Döderlein, } \\
\text { 1887) } \\
\text { Mugilidae }\end{array}$ & $\begin{array}{l}\text { Slender } \\
\text { wrasse }\end{array}$ & $\mathrm{LC}$ & $\begin{array}{l}\text { Carnivorous, small animals, } \\
\text { detritus, algae }\end{array}$ & - & - & 0.28 \\
\hline $\begin{array}{l}\text { Liza vaigeinsis (Quoy \& } \\
\text { Gaimard, 1825) }\end{array}$ & $\begin{array}{l}\text { Diamond- } \\
\text { scale grey } \\
\text { mullet }\end{array}$ & $\mathrm{LC}$ & $\begin{array}{l}\text { Phytoplankton, small algae, } \\
\text { detritus organisms }\end{array}$ & - & - & 0.85 \\
\hline \multicolumn{7}{|l|}{ Osphronemidae } \\
\hline $\begin{array}{l}\text { Trichopodus trichopterus } \\
\text { (Pallas, 1770) } \\
\text { Oxudercidae }\end{array}$ & $\begin{array}{l}\text { Three-spot } \\
\text { gourami }\end{array}$ & $\mathrm{LC}$ & $\begin{array}{l}\text { Omnivorous, aquatic plants } \\
\text { and some invertebrates }\end{array}$ & - & 12.95 & 16.15 \\
\hline $\begin{array}{l}\text { Periophthalmus gracilis (Eg- } \\
\text { gert, 1935) }\end{array}$ & $\begin{array}{l}\text { Graceful mud- } \\
\text { skipper }\end{array}$ & NE & Zooplanton, crustaceans & - & - & 0.28 \\
\hline
\end{tabular}


MD Ojao, EE Manatad, PA Logronio et al., 2021 / Physico-chemical Properties and Fish Composition

\begin{tabular}{|c|c|c|c|c|c|c|}
\hline Family/Species & $\begin{array}{l}\text { Common } \\
\text { Name }\end{array}$ & $\begin{array}{l}\text { IUCN } \\
\text { Status }\end{array}$ & Feeding Habit & Station 1 & Station 2 & Station \\
\hline \multicolumn{7}{|l|}{ Rhyacichthyidae } \\
\hline $\begin{array}{l}\text { Rhyacichthys aspro (Valenci- } \\
\text { ennes, 1837) }\end{array}$ & Loach goby & $\mathrm{DD}$ & Algae, diatoms & - & 0.52 & 0.28 \\
\hline \multicolumn{7}{|l|}{ Scatophagidae } \\
\hline $\begin{array}{l}\text { Scatophagus argus (Linnaeus, } \\
1766 \text { ) }\end{array}$ & Spotted scat & LC & $\begin{array}{l}\text { Plants matter, algae, worm, } \\
\text { crustaceans, insects }\end{array}$ & - & - & 0.57 \\
\hline \multicolumn{7}{|l|}{ Syngnathidae } \\
\hline $\begin{array}{l}\text { Doryichthys boaja (Bleeker, } \\
\text { 1850) }\end{array}$ & $\begin{array}{l}\text { Long-snout- } \\
\text { pipefish }\end{array}$ & $\mathrm{DD}$ & $\begin{array}{l}\text { Fish larvae, come inverte- } \\
\text { brates, plakton }\end{array}$ & - & - & 0.28 \\
\hline \multicolumn{7}{|l|}{ Toxotidae } \\
\hline $\begin{array}{l}\text { Toxotes jaculatrix (Pallas, } \\
\text { 1767) }\end{array}$ & $\begin{array}{l}\text { Banded arch- } \\
\text { erfish }\end{array}$ & LC & $\begin{array}{l}\text { Omnivorous, small fish, } \\
\text { other invertebrates }\end{array}$ & - & - & 0.28 \\
\hline \multicolumn{7}{|l|}{ Zenarchopteridae } \\
\hline $\begin{array}{l}\text { Zenarchopterus dispar (Va- } \\
\text { lenciennes, 1847) }\end{array}$ & $\begin{array}{l}\text { Feathered } \\
\text { river garfish }\end{array}$ & LC & Smaller fish, crabs & - & - & 0.28 \\
\hline \multicolumn{4}{|c|}{ Overall Relative abundance $(\%)$ per station: } & 31.15 & 24.34 & 44.51 \\
\hline \multicolumn{4}{|c|}{ Species Richness: } & 3 & 9 & 23 \\
\hline \multicolumn{3}{|c|}{ Shannon-Weiner Index: } & 1.89 & & & \\
\hline \multicolumn{3}{|c|}{ Simpson's Dominance Index (D): } & 1.24 & & & \\
\hline
\end{tabular}

Legend: $\left({ }^{\mathrm{N}}\right)$ native; $\left({ }^{\mathrm{E}}\right)$ endemic; $\left({ }^{\mathrm{IS}}\right)$ introduced species; $\left({ }^{\mathrm{IES}}\right)$ invasive alien species
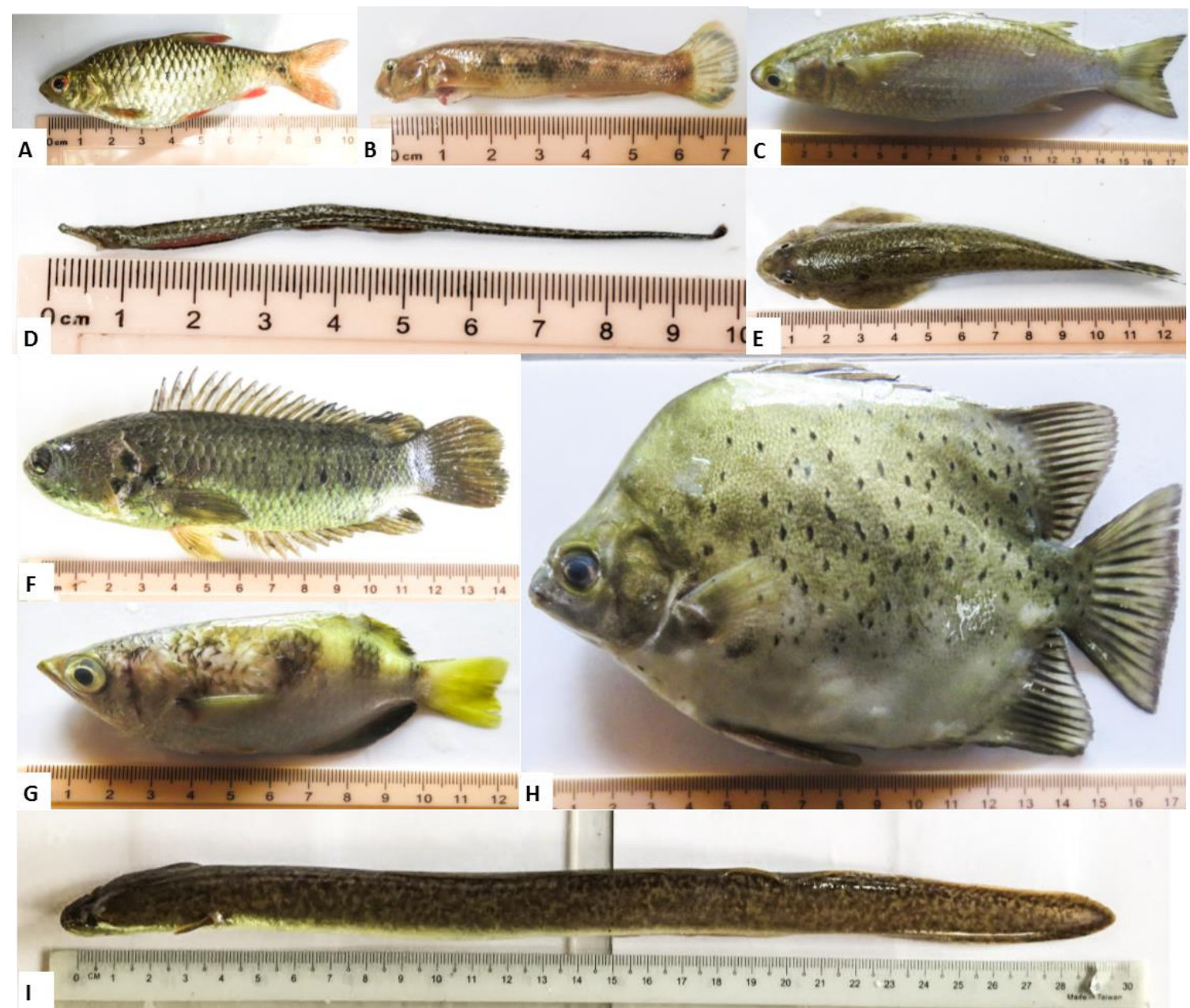

Figure 2. Some native fish species of Ihawan Spring Community Watershed (ISCW), Tandag, Surigao del Sur (A) P. binotatus; (B) S. lagocephalus; (C) L. vaigensis; (D) D. boaja; (E) R. aspro; (F) A. testudineus; (G) T. jaculatrix; (H) S. argus; (I) A. marmorata). CM.G.Cudal 
$\mathrm{mg} / \mathrm{L}$. The high record (> $5 \mathrm{mg} / \mathrm{L}$ ) of dissolved oxygen which is observed from all the study stations signifies a favorable condition for the freshwater fish population to thrive in the area. The difference value recorded in-between stations could be attributed to the presence of riffles which physically vary from site to site. The physical appearance of the upstream station is more rapid due to the number of rocks and other debris. Dissolved oxygen in the freshwater is relatively high because visually the stream bed is rocky and it contributed to the increase of dissolved oxygen in the water.

\section{Species composition and abundance}

A total of 793 individuals representing $21 \mathrm{fam}$ ilies from 22 genera belonging to 23 species were collected in Ihawan Spring Community Watershed, Tandag, Surigao del Sur (Table 2; Figure 2). Out of the 21 families, Butidae and Eleotridae had the highest species composition (8.70\%). Hence, this study documented one endemic species (B. expatria); two (2) introduced species (Trichopodus trichopterus and Channa striata) and one (1) Invasive Alien Species (Oreochromis niloticus). The $O$. niloticus or Nile tilapia has been recently classified as Invasive Alien Freshwater Fish Species in Philippines (DERN-BMB, 2016). Among the sampled station, downstream harbors the highest account of species (23 spp.), whereas, the upstream has the least ( $3 s p p$ ).

Based on relative abundance per species, the native Puntius binotatus accounts for the highest percentage recorded in upstream $(61.54 \%)$, midstream (58.03\%), and downstream (60.62\%). Whereas, only a diminutive number of Butis butis, Butis amboinensis, Diodon holocanthus, Bostrychus expatria, Kuhlia rupestris, Suezichthys gracilis, Rhyacichthys aspro, Doryichthys boaja, Toxotes jaculatrix, and Zenarchopterus dispar were collected. During rainy season, it is expected that some freshwater fishes were carried downstream and flourish down into the coastal waters. The study of [15] revealed that the species abundance in the freshwater ecosystem may be influence by the food availability, type habitat, and source of water pollution from domestic, agriculture, quarry, and mining activities. In terms of species relative abundance per site (Table 2), downstream accounts the highest abundance (44.51\%), followed by the upstream (31.15\%) and midstream (24.34\%) as the least. Consistent with the study findings, [16, 12, 17, 18] also reported high abun- dance of species from the downstream to upstream station.

The Ihawan Spring Community Watershed (ISCW) supports a high diversity of fish fauna comprising 21 families from 22 genera belonging to 23 species. In terms of biological indices, species diversity is found to be high (1.89), wherein in a natural ecosystem, values ranging from 1.5 3.5 is considered to be high value of diversity index [19]. The high Shannon-Weiner diversity index of the sampling area is attributed to the numbers of species taxa present and ratio of individuals for each species [20]. The account high number of native species indicates the healthy state of the freshwater ecosystem of Ihawan Spring Community Watershed. However, the presence of recently classified Invasive Alien Species of $O$. niloticus or Nile tilapia may attribute a negative impact in the river that may result in the possible decline of native freshwater fish species present in the area.

\section{Conclusion}

The locals play a significant role in conserving the freshwater ecosystem of Ihawan Spring Community Watershed and its environs by maintaining the cleanliness of the river such that no visitors are allowed to pee and disposed of human manure approximately 5 meters from the river banks. Use of electric fishing and other destructive methods is also prohibited except for research purposes, which may result in the decline of their freshwater fish species which is alternatively used for food consumption by some locals. They are much aware of the consequences and the extent of damage, it may cause to the river if cleanliness in the river is not maintained and illegal practices in fishing like electric fishing are not prohibited, since the watershed is the main source of water for domestic use in most of Tandag, Surigao del Sur.

To surmise, extensive ichthyofauna surveys should be done to potentially discover additional species and further assess the under-recorded fish species in the area. Likewise, monitoring study on the abundant of the Invasive Alien Species of O.niloticus and other recorded introduced species of freshwater fish is highly recommended to update their population status and assess the possibility that it may likely replace the existing native freshwater fish species in the area. Further, seasonal sampling (wet and dry) and additional. Physico-chemical parameters like turbidity, total dissolved solids, etc. should be done to monitor fluc- 
tuations trends on the physico-chemical parameter and to establish the real profile of Ihawan Spring Community Watershed, Tandag, Surigao del Sur.

\section{Acknowledgement}

The authors would like to thank Surigao del Sur State University -College of Teachers Education for the academic and technical support received. Special thanks are also extended to the locals who serve as the leading guide and local researcher throughout the fieldwork. And lastly, to the Tandag City Water District office for the technical assistance and permission received.

\section{References}

1. Dudgeon D, Arthington AH, Gessner MO et al. (2005) Freshwater biodiversity: importance, threats, status and conservation challenges. Biology Reviews 81:163-182.

2. Jenkins M (2003) Prospect of Biodiversity. Science 302: 1175-1177.

3. Abell R, Allan JD, Lehner B (2007) Unlocking the potential of protected areas for freshwaters. Biological Conservation 134: 48-63.

4. Hashemi SA, Ghorbani R, Kymaram F et al. (2015) Fish Species Composition, Distribution and Abundance in Shadegan Wetland. Fisheries and Aquaculture Journal 6 (2): 1 - 8. doi: 10.4172/2150-3508.1000128.

5. Pusey BJ, Arthington AH, Stewart-Koster B et al. (2010) Widespread omnivory and low temporal and spatial variation in the diet of fishes in a hydrologically variable northern Australian river. Journal of Fish Biology 77: 731-753.

6. Labatos BV, Briones ND (2014) Freshwater Fishes of Tikub Lake, Tiaong, Quezon, Philippines. Asian Scientific Journals 5 (1): $41-53$.

7. Ward JV, Tockner K (2001) Biodiversity: Towards a unifying theme for river ecology. Freshwater Biology 46: 807-819.

8. Massoud MA, El-Fadel M, Scrimshaw MD, Lester JN (2006) Factors influencing development of management strategies for the Abou Ali River in Lebanon. I: spatial variation and land use. Science of the Total Environment 362 (1-3): 15-30

9. Boyd CE, Tucker CS (2012) Pond aquaculture water quality management. Berlin, Germany: Springer Science \& Business Media.
10. Al-Badaii F, Shuhaimi-Othman M, Gasim MB (2013) Water Quality Assessment of the Semenyih River, Selangor, Malaysia. Journal of Chemistry. doi: 10.1155/2013/871056.

11. Froese R, Pauly D (Eds.) (2018) Fishbase. World Wide Web electronic publication. www.fishbase.org. accesed date: October 2018.

12. Quimpang VT, Cudal MG, Opiso EM et al. (2019) Fish Abundance and Physico-chemical Properties of Matingao River and Marbel River, Mount Apo Natural Park, Mindanao, Philippines. Central Mindanao University Journal of Science 4 (1): 14-19.

13. Quimpang VT, Opiso EM, Cudal MG et al. (2015) Assessment and Monitoring of Fish Species in the Mountain Streams and Lake of Mindanao LTER Sites. Asian Journal of Biodiversity (6) 1: $100-121$. doi: 10.7828/ajob.v6i1.697

14. Department of Environment and Natural Resources-Biodiversity Management Bureau (DENR-BMB) (2016) The National Invasive Species Strategy and Action Plan 20162026 (Philippines). Quezon City: Department of Environment Biodiversity Management Bureau and Natural Resources. pp. i-xix, 1-97.

15. Vedra SA, Ocampo PP, de Lara AV et al. (2013) Indigenous Goby Population in Mandulog River System and its Conservation by Communities in Iligan City, Philippines. Journal of Environmental Science and Management 16 (2): 11-18.

16. Aryani N, Suharman I, Azrita A et al. (2019) Diversity and distribution of fish fauna of upstream and downstream areas at Koto Panjang Reservoir, Riau Province, Indonesia. F100Reseacrh 8: 1435. doi: 10.12688/f1000research.19679.2

17. Quindo, JPV, Bucol LA, Bucol AA, Wagey BT (2019) Abundance and Diversity of Fishes in Bayawan River, Negros Oriental, Philippines. Jurnal Ilmiah Sains 19 (2): $118-134$.

18. Cudal M, Calimbo LG, Larede BG, Locson JB (2019) Freshwater fish species composition of Mount Timolan Protected Landscape, Zamboanga del Sur. University of Mindanao International Multidisciplinary Research Journal 4 (1): 76-86.

19. Maguran AE (2004) Measuring Ecological Diversity. Blackwell Publishing, Oxford. 256 pp.

20. Paller VGV, Corpuz MNC, Bandal MZ Jr (2017) Freshwater Fish Assemblages and Water Quality Parameters is Seven Lakes of San Pablo, Laguna, Philippines. Asian Journal of Biodiversity 8 (1): 1 - 22. 
This page is intentinonally left blank. 